\section{Common Smut Reduces Sweet Corn Yield and Ear Processing Quality}

\author{
George H. Clough ${ }^{\mathbf{1}}$ and Sarah Blatchford \\ Department of Horticulture, Oregon State University, Hermiston Agricultural \\ Research and Extension Center, 2121 S. 1st Street, Hermiston, OR 97838
}

\section{Philip B. Hamm}

Department of Botany and Plant Pathology, Oregon State University, Hermiston Agricultural Research and Extension Center, 2121 S. 1st Street, Hermiston, OR 97838

Additional index words. Zea mays, Ustilago maydis, ear diameter, ear length, kernel depth

\begin{abstract}
The impact of natural infection of Ustilago maydis (causal agent of common smut) on processing characteristics of three $F_{1}$ hybrid sweet corn (Zea mays $L$.) cultivars was evaluated in a 2-year study with early and late spring planting dates. At harvest maturity, size and location of galls were recorded and quality characteristics measured. Galls on the lower stalk, upper stalk, and tassel reduced fresh weight and diameter of husked ears, whereas galls on the base of the stalk reduced fresh weight only. Ear length was reduced by galls on the upper stalk. As gall size increased from 0 to greater than $\mathbf{1 0 . 2}$ $\mathrm{cm}$ in diameter, ear fresh weight and diameter decreased. The presence of galls greater than $10.2 \mathrm{~cm}$ in diameter reduced ear length. Kernel depth was unaffected by size or location of gall. Additional ears of the same three cultivars were sampled from commercial fields planted in midseason near Walla Walla and Patterson, WA. Galls located on the upper and lower stalk reduced fresh weight, length, and diameter, whereas galls on the base of the stalk reduced fresh weight only. As gall size increased, fresh weight, length, diameter, and kernel depth decreased.
\end{abstract}

Oregon and Washington produce $30 \%$ of the U.S. processed sweet corn with a 2009 farm market value of $\$ 120,512,000$ (U.S. Department of Agriculture, 2009). The majority is produced in the Columbia Basin (central Washington and north-central Oregon) with yields averaging $23.5 \mathrm{t} \cdot \mathrm{ha}^{-1}$. The area under production of processing sweet corn increased from $\approx 24,600$ ha in 1987 to 56,000 ha in 2002 .

Common smut, caused by the fungus Ustilago maydis, occurs worldwide and can cause yield losses in dent corn that range from a trace to $10 \%$ (White, 1999). Losses occur when galls replace the kernels of the ear or when a gall on the plant causes the quality of the ear to decrease. Losses resulting from common smut on sweet corn crops can be much greater as a result of the high susceptibility of flint corn, an ancestor of sweet corn (Bowjanowski, 1969). Fungicides are not effective in controlling this disease (Clough et al., 2001, 2003).

Since 1996, the incidence of common smut of sweet corn and field corn in the Columbia Basin of Oregon and Washington has increased from non-detectable levels to infection of most fields throughout the region (Clough et al., 2002). Increased area of production and

\footnotetext{
Received for publication 26 Apr. 2011. Accepted for publication 7 Sept. 2011.

Funding to support this work was provided by the Oregon Processed Vegetable Commission.

We express appreciation to Watts Brothers Farms, Kennewick, WA, for their assistance in providing commercial locations for this work.

${ }^{1}$ To whom reprint requests should be addressed; e-mail george.clough@oregonstate.edu.
}

dependence on smut-susceptible cultivars may have been responsible. The extent of losses resulting from common smut in sweet corn has not been determined, but major damage has been reported by the sweet corn processing industry since that time. Processing losses have been the result of increased labor costs for removing smutted ears, purchase of additional processing equipment to clean smutted corn, and end-product contamination by spores in the wash water resulting in unacceptable quality of ear cobbettes. Direct grower losses have occurred as a result of heavily smutted fields being "passed over" for harvest.

Yield losses resulting from common smut have in the past been attributed primarily to infection of the ear itself. The objective of the work reported here was to determine whether a relationship exists between ear quality and galls located elsewhere on the corn plant. Previous research from the early 1900s suggests that there is quality loss to the ear when the plant is infected with a smut gall (Immer and Christensen, 1928; Johnson and Christensen, 1935); however, an assessment of loss on infected modern sweet corn cultivars has not been explored.

\section{Materials and Methods}

Plots were seeded to 76,000 plants/ha on 4 May and 13 June in 2002 and on 2 May and 6 June in 2003 on the Hermiston Agricultural Research and Extension Center (HAREC) on Adkins fine sandy loam (coarse-loamy, mixed mesic Xerollic Camborthid, pH 6.7, 0.9\% organic matter). The four $9.2-\mathrm{m}$ rows/plot were spaced $0.76 \mathrm{~m}$ apart. The three hybrids evaluated, 'Sheba' (Seminis, Nampa, ID), 'Sockeye' (Harris Moran Seed Co., Modesto, CA), and 'Supersweet Jubilee' (Rogers, Boise, ID), represented early, mid, and late maturing varieties (1510, 1687, and 1750 heat units), respectively. Normal commercial production practices were followed (Oregon State University Cooperative Extension Service, 2004). The experimental design was a randomized complete block with four replications.

Ear maturity was determined using the microwave procedure developed by Becwar et al. (1977). Ears with the sugary ( $s u$ ) endosperm mutants ('Sockeye') were harvested when kernel moisture ranged from $71 \%$ to $74 \%$ and ears of the shrunken $2\left(s h_{2}\right)$ endosperm mutants ('Sheba', 'Supersweet Jubilee') were harvested in the $75 \%$ to $77 \%$ moisture range.

For each planting date, and at optimum moisture, ears were sampled from plants with either no gall or only a single gall. Gall location on the plant was recorded as on the base (between brace roots and soil), lower stalk (between base and ear), upper stalk (between ear and tassel), or tassel. Gall size (0, less than 5, 5.1 to 10.2 , greater than $10.2 \mathrm{~cm}$ diameter) was measured and recorded, and fresh weight, length, diameter, and kernel depth of the husked ear were measured. Data were subjected to analysis of variance by SAS General Linear Model procedures with mean separation by Fisher's protected least significant difference (PROC GLM; SAS Institute Inc., 2004) to determine the impact of gall location and size on these important processing characteristics (Stall et al., 1989).

In 2003, additional ears of the same cultivars were sampled from four locations in three commercial fields, each planted to one cultivar, in late June near Walla Walla and Patterson, WA. Field sampling technique and quality evaluation were as previously described except 'Supersweet Jubilee' was detasseled before harvest, so effects associated with tassel location could not be evaluated.

\section{Results}

Experiment station trials. In the early planting in 2002, no galls were found on the base or upper stalk for 'Sockeye', and only small galls (less than $5.1 \mathrm{~cm}$ ) were noted at the other locations. Galls did not occur on the lower or upper stalks for 'Sheba', and with the later planting, there were no galls on the upper stalk.

In the early planting in 2003, no galls were found on the base or lower or upper stalk for 'Sockeye', and none were observed at any location for 'Sheba'. Galls were not found on the lower stalk or tassels of 'Supersweet Jubilee' with the early planting or on the tassels with the later planting. This resulted in several minor interactions affecting fresh weight and diameter involving year, planting, cultivar, gall location, and gall size (Table 1).

Only $1.7 \%$ of the 1128 plants sampled had a gall on the tassel larger than $10.2 \mathrm{~cm}$ in 
Table 1. Sweet corn ear quality as affected by year, planting, cultivar, gall location, and gall size in Ustilago maydis-infected plants in 2002 and 2003 at Hermiston, OR.

\begin{tabular}{|c|c|c|c|c|}
\hline & Fresh wt (g) & $\operatorname{Diam}(\mathrm{cm})$ & Length $(\mathrm{cm})$ & Kernel depth $(\mathrm{cm})$ \\
\hline \multicolumn{5}{|l|}{$\overline{\text { Year }(\mathrm{Y})}$} \\
\hline 2002 & 274 & 4.67 & 21.0 & 0.84 \\
\hline \multirow[t]{2}{*}{2003} & 288 & 4.92 & 20.3 & 1.02 \\
\hline & $* * *$ & $* * * *$ & NS & $* * * *$ \\
\hline \multicolumn{5}{|l|}{ Planting (P) } \\
\hline Early & 284 & 4.84 & 20.5 & 0.97 \\
\hline \multirow[t]{2}{*}{ Late } & 277 & 4.74 & 21.2 & 0.88 \\
\hline & NS & $* * *$ & ** & * \\
\hline \multicolumn{5}{|l|}{ Cultivar $^{\mathrm{z}}(\mathrm{C})$} \\
\hline Sheba & $285 \mathrm{a}$ & $4.85 \mathrm{a}$ & $21.2 \mathrm{a}$ & $0.91 \mathrm{ab}$ \\
\hline Sockeye & $262 \mathrm{~b}$ & $4.67 \mathrm{~b}$ & $20.6 \mathrm{~b}$ & $0.86 \mathrm{~b}$ \\
\hline \multirow[t]{2}{*}{ Supersweet Jubilee } & $296 \mathrm{a}$ & $4.83 \mathrm{a}$ & $21.1 \mathrm{a}$ & $0.96 \mathrm{a}$ \\
\hline & $* * * *$ & $* * * *$ & $* * * *$ & $*$ \\
\hline \multicolumn{5}{|l|}{ Gall location (L) } \\
\hline None & $297 \mathrm{a}$ & $4.89 \mathrm{a}$ & $21.2 \mathrm{a}$ & 0.96 \\
\hline Base & $282 \mathrm{~b}$ & $4.81 \mathrm{ab}$ & $20.8 \mathrm{ab}$ & 0.91 \\
\hline Lower stalk & $251 \mathrm{c}$ & $4.57 \mathrm{c}$ & $20.6 \mathrm{~b}$ & 0.86 \\
\hline Upper stalk & $242 \mathrm{c}$ & $4.45 \mathrm{~d}$ & $19.9 \mathrm{c}$ & 0.84 \\
\hline \multirow[t]{2}{*}{ Tassel } & $281 \mathrm{~b}$ & $4.77 \mathrm{~b}$ & $21.1 \mathrm{a}$ & 0.88 \\
\hline & $* * * *$ & $* * * *$ & $* *$ & NS \\
\hline \multicolumn{5}{|l|}{ Gall size $(\mathrm{cm})(\mathrm{S})$} \\
\hline 0 & $297 \mathrm{a}$ & $4.89 \mathrm{a}$ & $21.2 \mathrm{a}$ & 0.96 \\
\hline Less than 5.1 & $277 \mathrm{~b}$ & $4.75 \mathrm{~b}$ & $20.9 \mathrm{ab}$ & 0.88 \\
\hline $5.1-10.2$ & $266 \mathrm{c}$ & $4.65 \mathrm{c}$ & $20.8 \mathrm{~b}$ & 0.87 \\
\hline \multirow[t]{2}{*}{ Greater than 10.2} & $239 \mathrm{~d}$ & $4.51 \mathrm{~d}$ & $20.3 \mathrm{c}$ & 0.84 \\
\hline & $* * * *$ & $* * * *$ & $* *$ & NS \\
\hline \multicolumn{5}{|l|}{ Interactions } \\
\hline $\mathrm{Y} \times \mathrm{L}$ & $* *$ & NS & NS & NS \\
\hline $\mathrm{P} \times \mathrm{L}$ & * & NS & NS & NS \\
\hline $\mathrm{Y} \times \mathrm{P} \times \mathrm{L}$ & $*$ & $* * * *$ & NS & NS \\
\hline $\mathrm{C} \times \mathrm{L}$ & * & NS & NS & NS \\
\hline $\mathrm{P} \times \mathrm{S}$ & * & NS & NS & NS \\
\hline $\mathrm{P} \times \mathrm{C} \times \mathrm{S}$ & $*$ & NS & NS & NS \\
\hline $\mathrm{L} \times \mathrm{S}$ & * & * & NS & NS \\
\hline
\end{tabular}

${ }^{\mathrm{z}}$ Cultivar means of uninfected controls.

****, ***,**,*, ns Significant at $P \leq 0.0001, P \leq 0.001, P \leq 0.01, P \leq 0.05$, or nonsignificant, respectively. Means followed by different letters are significantly different at $P=0.05$ (Fisher's protected least significant difference).

diameter, and $89 \%$ of tassels observed had no gall or a gall less than $5.1 \mathrm{~cm}$ in size, resulting in cultivar $\times$ gall location and gall location $x$ size interactions.

Sweet corn ear fresh weight was greater in 2003 than in 2002 but was unaffected by time of planting (Table 1). Ear fresh weight was greater for 'Supersweet Jubilee' and 'Sheba' than for 'Sockeye'. A gall on the base or tassel of the plant reduced ear fresh weight, which was further reduced by a gall on the lower or upper stalk. Ear fresh weight decreased as gall size increased.

Ear fresh weight was influenced by interactions between year, planting and gall location, cultivar and gall location, planting, cultivar and gall size, and gall location and gall size. Fresh weight was reduced by a gall on the lower stalk and further reduced by a gall on the upper stalk for the 2002 early planting (data not shown). With the later planting, galls at both locations reduced ear fresh weight, but the decrease was not statistically significant for a gall on the upper stalk. In the 2003 early planting, no galls were found on the lower stalk and only a gall on the tassels reduced ear fresh weight. Galls at all locations reduced ear fresh weight for the 2003 late planting with the largest decrease from a gall on the upper stalk.

Ear fresh weight was reduced by galls at all locations with 'Sockeye' and 'Supersweet
Jubilee' but was reduced only by a gall on the lower stalk with 'Sheba' (Table 2).

With the early planting date, gall size did not affect ear fresh weight for 'Sheba' but fresh weight decreased with a gall 5.1 to $10.2 \mathrm{~cm}$ in diameter for 'Sockeye' and decreased as gall size increased for 'Supersweet Jubilee' (Table 3). With the late planting, fresh weight decreased as gall size increased for both 'Sockeye' and 'Supersweet Jubilee' but only decreased with the largest sized gall (greater than $10.2 \mathrm{~cm}$ ) for 'Sheba'.

On the base and tassels of the plant, only the largest gall reduced ear fresh weight (Table 4). A gall of any size decreased fresh weight if on the lower stalk with the largest reduction occurring with the largest gall. A gall of 5.1 to $10.2 \mathrm{~cm}$ on the upper stalk reduced ear fresh weight, whereas a gall greater than $10.2 \mathrm{~cm}$ in diameter further decreased ear weight.

Ear diameter was greater in 2003 than in 2002, decreased from the early to later planting, and decreased as gall size increased (Table 1). Diameter decreased with a gall on the tassel, decreased further with a gall on the lower stalk, but was reduced most when the gall was located on the upper stalk. However, ear diameter was affected by interactions between year, time of planting and gall location, and gall size and gall location.
Table 2. Sweet corn ear fresh weight as affected by cultivar and gall location interaction in Ustilago maydis-infected plants in 2002 and 2003 at Hermiston, OR.

\begin{tabular}{lccc}
\hline & \multicolumn{3}{c}{ Cultivar } \\
\cline { 2 - 4 } Gall & Sockeye & Sheba & Supersweet Jubilee \\
\cline { 2 - 4 } location & \multicolumn{3}{c}{ Wt $(\mathrm{g})$} \\
\hline None & $278 \mathrm{a}$ & $290 \mathrm{a}$ & $322 \mathrm{a}$ \\
Base & $241 \mathrm{c}$ & $273 \mathrm{ab}$ & $296 \mathrm{~b}$ \\
Lower & $229 \mathrm{c}$ & $239 \mathrm{~b}$ & $277 \mathrm{c}$ \\
Upper & $234 \mathrm{c}$ & $257 \mathrm{ab}$ & $242 \mathrm{~d}$ \\
Tassel & $270 \mathrm{~b}$ & $291 \mathrm{a}$ & $301 \mathrm{~b}$ \\
& $* * * *$ & $*$ & $* * *$ \\
\hline$* * * *, *$ Significant at $P \leq 0.0001$ or $P \leq 0.05$,
\end{tabular}

****, *Significant at $P \leq 0.0001$ or $P \leq 0.05$, respectively. Means followed by different letters are significantly different at $P=0.05$ (Fisher's protected least significant difference).

In 2002 with the early planting date, ear diameter was reduced by a gall on the lower stalk and further decreased by a gall on the upper stalk (data not shown). With the later planting, a gall at either location reduced ear diameter similarly. Gall location did not affect ear diameter with the early planting in 2003. With the later planting, however, a gall on the tassels reduced ear diameter, a gall on the lower stalk further decreased the diameter, whereas an upper stalk gall produced the smallest diameter ear.

Ear diameter was unaffected by galls on the base of the plant but was reduced by the presence of galls on the lower stalk (Table 5). A gall less than $5.1 \mathrm{~cm}$ on the upper stalk did not impact ear diameter, but a gall from 5.1 to $10.2 \mathrm{~cm}$ decreased ear diameter, and a gall greater than $10.2 \mathrm{~cm}$ decreased ear diameter further. On the tassel, only a gall greater than $10.2 \mathrm{~cm}$ decreased ear diameter.

Ear length was similar in 2002 and 2003 and increased slightly from the early to the late planting (Table 1). Ears of 'Sheba' and 'Supersweet Jubilee' were similar in length and longer than those of 'Sockeye'. Ear length was reduced by a gall on the lower or upper stalk and by a gall of $5.1 \mathrm{~cm}$ or larger.

Kernel depth was greater in 2003 than 2002, decreased from the early to late planting, and differed between cultivars but was not influenced significantly by either gall location or gall size.

Commercial trials. Results similar to those of the experiment station plantings were obtained from the commercial production fields. 'Sockeye' ear fresh weight was reduced by a gall on the base and further decreased by a lower stalk gall; none were found on the upper stalk (Table 6). Ear diameter also decreased with a gall on either the base or lower stalk, whereas ear length and kernel depth were reduced only by a gall found on the lower stalk. Ear weight tended to decrease as gall size increased, but only a gall greater than 10.2 $\mathrm{cm}$ significantly reduced ear weight. Diameter, length, and kernel depth were unaffected by gall size.

Ear fresh weight of 'Sheba' was reduced by a gall on the base, decreased further by a lower stalk gall, but reduced the most by a gall on the upper stalk (Table 7). Both 
Table 3. Sweet corn ear fresh weight as affected by cultivar, planting and gall size interaction in Ustilago maydis-infected plants in 2002 and 2003 at Hermiston, OR.

\begin{tabular}{|c|c|c|c|c|c|c|}
\hline \multirow[b]{4}{*}{ Gall size $(\mathrm{cm})$} & \multicolumn{6}{|c|}{ Cultivar } \\
\hline & \multicolumn{2}{|c|}{ Sockeye } & \multicolumn{2}{|c|}{ Sheba } & \multicolumn{2}{|c|}{ Supersweet Jubilee } \\
\hline & Early & Late & Early & $\overline{\text { Late }}$ & Early & Late \\
\hline & \multicolumn{6}{|c|}{$\mathrm{Wt}(\mathrm{g})$} \\
\hline$\overline{0}$ & $280 \mathrm{a}$ & $275 \mathrm{a}$ & 277 & $295 \mathrm{a}$ & $327 \mathrm{a}$ & $317 \mathrm{a}$ \\
\hline Less than 5.1 & $280 \mathrm{a}$ & $252 \mathrm{~b}$ & 270 & $290 \mathrm{a}$ & $285 \mathrm{~b}$ & $307 \mathrm{ab}$ \\
\hline $5.1-10.2$ & $202 \mathrm{~b}$ & $230 \mathrm{c}$ & 305 & $285 \mathrm{a}$ & $265 \mathrm{~b}$ & $295 \mathrm{~b}$ \\
\hline Greater than 10.2 & $\begin{array}{c}237 \mathrm{ab} \\
*\end{array}$ & $\begin{array}{c}210 \mathrm{~d} \\
* * *\end{array}$ & - & $\begin{array}{c}237 \mathrm{~b} \\
* * *\end{array}$ & $\begin{array}{l}207 \mathrm{c} \\
* * * *\end{array}$ & $\begin{array}{r}262 \mathrm{c} \\
* * * *\end{array}$ \\
\hline
\end{tabular}

****,***,*, Ns Significant at $P \leq 0.0001, P \leq 0.001, P \leq 0.05$, or non-significant, respectively. Means followed by different letters significantly different at $P=0.05$ (Fisher's protected least significant difference).

Table 4. Sweet corn ear fresh weight as affected by gall location and gall size interaction in Ustilago maydis-infected plants in 2002 and 2003 at Hermiston, OR.

\begin{tabular}{lcccc}
\hline & \multicolumn{4}{c}{ Gall location } \\
\cline { 2 - 5 } Gall size $(\mathrm{cm})$ & Base & Lower stalk & Upper stalk & Tassel \\
\cline { 2 - 5 } & $297 \mathrm{a}$ & $297 \mathrm{a}$ & $297 \mathrm{a}$ & $297 \mathrm{a}$ \\
\hline 0 & $293 \mathrm{a}$ & $257 \mathrm{~b}$ & $294 \mathrm{a}$ & $280 \mathrm{ab}$ \\
Less than 5.1 & $282 \mathrm{ab}$ & $256 \mathrm{~b}$ & $256 \mathrm{~b}$ & $299 \mathrm{a}$ \\
$5.1-10.2$ & $271 \mathrm{~b}$ & $238 \mathrm{c}$ & $153 \mathrm{c}$ & $263 \mathrm{~b}$ \\
Greater than 10.2 & $* * *$ & $* * * *$ & $* * * * * *$ & $* * *$
\end{tabular}

****,***Significant at $P \leq 0.0001$ or $P \leq 0.001$, respectively. Means followed by different letters significantly different at $P=0.05$ (Fisher's protected least significant difference).

Table 5. Sweet corn ear diameter as affected by gall location and gall size interaction in Ustilago maydisinfected plants in 2002 and 2003 at Hermiston, OR.

\begin{tabular}{lcccr}
\hline & \multicolumn{4}{c}{ Gall location } \\
\cline { 2 - 5 } Gall size $(\mathrm{cm})$ & Base & Lower stalk & Upper stalk & Tassel \\
\cline { 2 - 5 } & 4.89 & $4.89 \mathrm{a}$ & Diam $(\mathrm{cm})$ \\
\hline 0 & 4.83 & $4.58 \mathrm{~b}$ & $4.89 \mathrm{a}$ & $4.89 \mathrm{a}$ \\
Less than 5.1 & 4.88 & $4.59 \mathrm{~b}$ & $4.91 \mathrm{a}$ & $4.78 \mathrm{a}$ \\
$5.1-10.2$ & 4.73 & $4.54 \mathrm{~b}$ & $4.52 \mathrm{~b}$ & $4.74 \mathrm{a}$ \\
Greater than 10.2 & NS & $* * *$ & $3.75 \mathrm{c}$ & $4.48 \mathrm{~b}$ \\
& & $* * *$ & $* *$ \\
\hline
\end{tabular}

****, **, Ns Significant at $P \leq 0.0001, P \leq 0.01$, or nonsignificant, respectively. Means followed by different letters are significantly different at $P=0.05$ (Fisher's protected least significant difference).

Table 6. 'Sockeye' sweet corn ear quality as affected by gall location and gall size in Ustilago maydisinfected plants, commercial fields in 2003.

\begin{tabular}{|c|c|c|c|c|}
\hline & Fresh wt (g) & Diam $(\mathrm{cm})$ & Length $(\mathrm{cm})$ & Kernel depth $(\mathrm{cm})$ \\
\hline \multicolumn{5}{|l|}{ Gall location } \\
\hline None & $264 a$ & $4.94 \mathrm{~b}$ & $19.3 \mathrm{a}$ & $0.89 \mathrm{ab}$ \\
\hline Base & $238 \mathrm{~b}$ & $4.75 \mathrm{c}$ & $19.3 \mathrm{ab}$ & $0.87 \mathrm{bc}$ \\
\hline Lower stalk & $232 \mathrm{c}$ & $4.64 \mathrm{c}$ & $18.4 \mathrm{~b}$ & $0.82 \mathrm{c}$ \\
\hline Upper stalk & - & - & - & - \\
\hline Tassel & $\begin{array}{r}282 \mathrm{a} \\
* * * *\end{array}$ & $\begin{array}{c}5.11 \mathrm{a} \\
* * * *\end{array}$ & $\begin{array}{c}20.1 \mathrm{a} \\
* *\end{array}$ & $\begin{array}{c}0.93 \text { a } \\
*\end{array}$ \\
\hline \multicolumn{5}{|l|}{ Gall size $(\mathrm{cm})$} \\
\hline 0 & $264 \mathrm{a}$ & 4.94 & 20.0 & 0.91 \\
\hline Less than 5.1 & $250 \mathrm{a}$ & 4.83 & 19.4 & 0.91 \\
\hline $5.1-10.2$ & $243 \mathrm{ab}$ & 4.90 & 19.2 & 0.89 \\
\hline \multirow[t]{2}{*}{ Greater than 10.2} & $218 b$ & 4.77 & 18.7 & 0.86 \\
\hline & $* *$ & NS & NS & NS \\
\hline
\end{tabular}

****,**,*, NS Significant at $P \leq 0.0001, P \leq 0.01, P \leq 0.05$, or nonsignificant, respectively. Means followed by different letters are significantly different at $P=0.05$ (Fisher's protected least significant difference).

diameter and length were reduced by a lower stalk gall and further reduced by a gall on the upper stalk. Kernel depth was unaffected by gall location. Fresh weight, diameter, and length were reduced by a gall $5.1 \mathrm{~cm}$ or greater, whereas kernel depth was reduced only by a 5.1- to $10.2-\mathrm{cm}$ gall. Ear fresh weight, diameter, and kernel depth were influenced by interactions between gall location and gall size. Fresh weight was reduced by a gall of $5.1 \mathrm{~cm}$ or larger on the base or lower stalk and by a small- or medium-sized gall on the upper stalk. There were no galls greater than $10.2 \mathrm{~cm}$ at that location and no medium or large galls on the tassel (data not shown). Ear diameter was unaffected by a gall on the base or tassels but was reduced by a gall greater than $10.2 \mathrm{~cm}$ on the lower stalk or a gall of 5.1 to $10.2 \mathrm{~cm}$ on the upper stalk. Kernel depth decreased only with a gall of 5.1 to $10.2 \mathrm{~cm}$ on the upper stalk.

Fresh weight, diameter, length, and kernel depth of 'Supersweet Jubilee' ears were unaffected by gall location (Table 8). Although they tended to decrease as gall size increased, fresh weight, diameter, and length were significantly reduced only by a gall greater than $10.2 \mathrm{~cm}$ in diameter. Kernel depth was unaffected by gall size. All cultivars were impacted by interactions between gall location and gall size. Fresh weight, diameter, length, and kernel depth were reduced only by a gall greater than $10.2 \mathrm{~cm}$ located on the upper stalk (data not shown).

\section{Discussion}

The data presented here indicate a yield loss beyond the direct ear loss (average 7.3\% for 6 cultivars evaluated over 12 years; Clough and Hamm, 2009) that occurs from an ear infection by common smut. In these trials, fresh weight loss of non-infected ears averaged $19.5 \%, 16 \%$, and $6.8 \%$ as a result of a single gall on the upper stalk, lower stalk, or stalk base, respectively; this translates into a significant additional tonnage loss coming out of the field. Galls on the upper stalk have the greatest impact, significantly decreasing ear length, diameter, and kernel depth. A gall on the lower stalk or base reduces ear diameter and length but does not affect kernel depth. Ear fresh weight decreased $6.3 \%$, $10.7 \%$, and $19.7 \%$ with a single gall less than $5.1 \mathrm{~cm}, 5.1$ to $10.2 \mathrm{~cm}$, or greater than $10.2 \mathrm{~cm}$, respectively. Ear diameter and length also decreased as gall size increased, whereas kernel depth was reduced only by a gall greater than $10.2 \mathrm{~cm}$. These changes in ear quality reduce processing uses and limit product recovery.

Yield of field corn plants infected with a single gall was reduced approximately $25 \%$ (Johnson and Christensen, 1935). A single gall between the ear and the tassel reduced yield approximately twice as much as a gall between the base of the plant and the ear. Yield was reduced $\approx 50 \%$ on plants that had multiple galls. Johnson and Christensen also reported large galls reduced yield more than small galls. Our results demonstrate that modern sweet corn hybrids respond similarly to field corn when infected by common smut.

Billett and Burnett (1978) found that increased dry weight of common smut-infected tissue was accompanied by a decrease in weight of other developing plant parts. As infection advanced, leaf development was delayed and leaf area was reduced. Dry weight reduction, however, was proportionately larger in the root than the shoot. The growth of the gall creates a sink for sucrose and other nutrients exported from photosynthetically active cells (Biemelt and Sonnewald, 2006). More recently, Horst et al. (2008) demonstrated that 
the establishment of $\mathrm{C}_{4}$ metabolism is prevented in common smut-infected leaf tissue, which would reduce the photosynthetic efficiency of the affected tissue.
Many of the year $\times$ planting date interactions in this data set occurred when ears of the first planting in 2003 were larger than in the second planting. Typically, ears of sweet

Table 7. 'Sheba' sweet corn ear quality as affected by gall location and gall size in Ustilago maydisinfected plants, commercial fields in 2003.

\begin{tabular}{|c|c|c|c|c|}
\hline & Fresh wt (g) & $\operatorname{Diam}(\mathrm{cm})$ & Length $(\mathrm{cm})$ & Kernel depth $(\mathrm{cm})$ \\
\hline \multicolumn{5}{|l|}{ Gall location (L) } \\
\hline None & $291 \mathrm{a}$ & $5.15 \mathrm{a}$ & $19.3 \mathrm{a}$ & 0.96 \\
\hline Base & $248 \mathrm{~b}$ & $5.03 \mathrm{ab}$ & $18.6 \mathrm{a}$ & 0.95 \\
\hline Lower stalk & $213 \mathrm{c}$ & $4.87 \mathrm{~b}$ & $16.8 \mathrm{~b}$ & 0.90 \\
\hline Upper stalk & $126 \mathrm{~d}$ & $4.24 \mathrm{c}$ & $12.1 \mathrm{c}$ & 0.76 \\
\hline \multirow[t]{2}{*}{ Tassel } & $295 \mathrm{a}$ & $5.21 \mathrm{a}$ & $19.7 \mathrm{a}$ & 0.98 \\
\hline & $* * * *$ & $*$ & $* * * *$ & NS \\
\hline \multicolumn{5}{|l|}{ Gall size $(\mathrm{cm})(\mathrm{S})$} \\
\hline 0 & $291 \mathrm{a}$ & $5.14 \mathrm{a}$ & $19.3 \mathrm{a}$ & $0.96 \mathrm{a}$ \\
\hline Less than 5.1 & $272 \mathrm{a}$ & $5.10 \mathrm{ab}$ & $18.8 \mathrm{a}$ & $0.96 \mathrm{a}$ \\
\hline $5.1-10.2$ & $199 \mathrm{~b}$ & $4.77 \mathrm{c}$ & $16.3 \mathrm{~b}$ & $0.84 \mathrm{~b}$ \\
\hline \multirow[t]{2}{*}{ Greater than 10.2} & $209 \mathrm{~b}$ & $4.88 \mathrm{bc}$ & $17.1 \mathrm{~b}$ & $0.92 \mathrm{a}$ \\
\hline & $* *$ & $* *$ & $* * *$ & $* * *$ \\
\hline \multicolumn{5}{|l|}{ Interactions } \\
\hline $\mathrm{L} \times \mathrm{S}$ & $*$ & $* * * *$ & NS & $* *$ \\
\hline
\end{tabular}

****,***,**,*, ns Significant at $P \leq 0.0001, P \leq 0.001, P \leq 0.01, P \leq 0.05$, or nonsignificant, respectively. Means followed by different letters are significantly different at $P=0.05$ (Fisher's protected least significant difference).

Table 8. 'Supersweet Jubilee' sweet corn ear quality as affected by gall location and gall size in Ustilago maydis-infected plants, commercial fields in 2003.

\begin{tabular}{|c|c|c|c|c|}
\hline & Fresh wt (g) & $\operatorname{Diam}(\mathrm{cm})$ & Length $(\mathrm{cm})$ & Kernel depth $(\mathrm{cm})$ \\
\hline \multicolumn{5}{|l|}{ Gall location (L) } \\
\hline None & 275 & 4.64 & 21.2 & 0.88 \\
\hline Base & 261 & 4.60 & 20.7 & 0.90 \\
\hline Lower stalk & 259 & 4.57 & 20.4 & 0.90 \\
\hline Upper stalk & 226 & 4.39 & 19.8 & 0.84 \\
\hline \multirow[t]{2}{*}{ Tassel $^{\mathrm{z}}$} & - & - & - & - \\
\hline & NS & NS & NS & NS \\
\hline \multicolumn{5}{|l|}{ Gall size $(\mathrm{cm})(\mathrm{S})$} \\
\hline 0 & $275 \mathrm{a}$ & $4.64 \mathrm{a}$ & $21.2 \mathrm{a}$ & 0.88 \\
\hline Less than 5.1 & $269 \mathrm{a}$ & $4.62 \mathrm{a}$ & $20.6 \mathrm{ab}$ & 0.90 \\
\hline $5.1-10.2$ & $272 \mathrm{a}$ & $4.67 \mathrm{a}$ & $21.0 \mathrm{a}$ & 0.93 \\
\hline \multirow[t]{2}{*}{ Greater than 10.2} & $224 \mathrm{~b}$ & $4.39 \mathrm{~b}$ & $19.8 \mathrm{~b}$ & 0.84 \\
\hline & $* * * *$ & $*$ & $*$ & NS \\
\hline \multicolumn{5}{|l|}{ Interactions } \\
\hline $\mathrm{L} \times \mathrm{S}$ & $* *$ & $*$ & $*$ & $*$ \\
\hline
\end{tabular}

${ }^{z}$ Detasseled before harvest.

$* * * *, * *, *$, NS Significant at $P \leq 0.0001, P \leq 0.01, P \leq 0.05$, or nonsignificant, respectively. Means followed by different letters are significantly different at $P=0.05$ (Fisher's protected least significant difference).

Table 9. Percent Ustilago maydis infections of sweet corn cultivars by gall location and gall size, Hermiston AREC (2002 and 2003) and commercial production fields (2003).

\begin{tabular}{|c|c|c|c|c|c|c|}
\hline & \multicolumn{3}{|c|}{ Hermiston AREC ${ }^{z}$} & \multicolumn{3}{|c|}{ Commercial fields $^{\mathrm{y}}$} \\
\hline & Sockeye & Sheba & Supersweet Jubilee & Sockeye & Sheba & Supersweet Jubilee \\
\hline & \multicolumn{6}{|c|}{ Percent } \\
\hline \multicolumn{7}{|l|}{ Gall location } \\
\hline None & 40 & 44 & 42 & 25 & 24 & 27 \\
\hline Base & 3 & 7 & 13 & 25 & 24 & 24 \\
\hline Lower stalk & 25 & 8 & 28 & 25 & 24 & 24 \\
\hline Upper stalk & 1 & 1 & 10 & 0 & 4 & 25 \\
\hline Tassel & 31 & 40 & 7 & 25 & 24 & $-x$ \\
\hline \multicolumn{7}{|l|}{ Gall size $(\mathrm{cm})$} \\
\hline 0 & 40 & 44 & 42 & 25 & 24 & 27 \\
\hline Less than 5.1 & 42 & 35 & 19 & 56 & 46 & 20 \\
\hline $5.1-10.2$ & 11 & 12 & 23 & 11 & 12 & 18 \\
\hline Greater than 10.2 & 7 & 8 & 16 & 8 & 18 & 35 \\
\hline
\end{tabular}

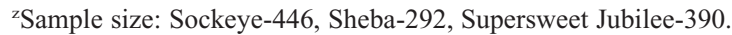

${ }^{y}$ Sample size: Sockeye-119, Sheba-119, Supersweet Jubilee-161.

${ }^{\mathrm{x}}$ Detasseled before harvest.

AREC $=$ Agricultural Research and Extension Center.

corn planted in June will be larger than from corn planted in May, but in 2003, extreme heat prevented the June planting from developing larger ears. The average temperature for June, July, and August was $28.6^{\circ} \mathrm{C}$ in 2002 and $31.0^{\circ} \mathrm{C}$ in 2003 . Not only was 2003 a hotter summer than 2002, but from 20 July 2003 to 1 Aug. 2003, the maximum temperature in Hermiston averaged $36.7^{\circ} \mathrm{C}$. This extreme heat occurred at the time the second planting was in the vegetative stage of development between planting and silking. According to Hortik and Arnold (1965), when the air temperature exceeds $29^{\circ} \mathrm{C}$, there is a reduction of vegetative growth. This explains reductions in ear quality measurements at the time of harvest maturity in the second planting of 2003.

Other interactions were the result of lack of galls at some locations with some cultivars, limited number of plants with galls on the upper stalk, and lack of galls in all size categories (primarily galls larger than $10.2 \mathrm{~cm}$ ) at all locations (Table 9). Relying on natural infection and the limited number of plants to sample at the HAREC location (210/plot) resulted in a wide range of sample sizes and unequal distribution of gall location and size. A more uniform, although still somewhat skewed sample size was obtained from the commercial production fields, where there was a greater number of plants available for sampling. In general, more plants were found to have galls on the lower stalk, followed by the tassel, with the greatest percentage of galls less than $5.1 \mathrm{~cm}$ in diameter.

Data from the field trials and the commercial fields were similar. Quality characteristics were reduced by a gall on the base or tassel of the plant, but the greatest impact occurred when the gall was on the upper followed by the lower stalk of the plant. The larger the gall size, the greater the impact on ear quality.

All three of the sweet corn cultivars used in this study were susceptible to common smut, although some data collected would suggest that 'Supersweet Jubilee' was more susceptible or impacted more severely by infection (Clough et al., 2002, 2003). With the lack of fungicides that are efficacious in controlling this disease, other means of disease management such as cultivar resistance may be an important component in the future. Information assessing the relative susceptibility of sweet corn cultivars is needed, particularly their response to this disease in the Columbia Basin of Oregon and Washington.

\section{Literature Cited}

Becwar, M.R., N.S. Monsour, and G.W. Varseveld. 1977. Microwave drying: A rapid method for determining sweet corn moisture. HortScience 12:562-563

Biemelt, S. and U. Sonnewald. 2006. Plant-microbe interactions to probe regulation of plant carbon metabolism. J. Plant Physiol. 163:307-318.

Billett, E.E. and J.H. Burnett. 1978. The hostparasite physiology of the maize smut fungus, Ustilago maydis I. The effect of smut infection 
on maize growth. Physiol. Plant Pathol. 12:93102.

Bowjanowski, J. 1969. Studies of inheritance of reaction to common smut in corn. Theor. Appl. Genet. 39:32-42.

Clough, G. and P. Hamm. 2009. Cultivar evaluation for control of common smut in sweet corn in the Columbia Basin. 2009-2010 Rpt. Agr. Res. Foundation Ore. Processed Veg. Commission. p. 108-115.

Clough, G., P. Hamm, S. Blatchford, and L. du Toit. 2002. Control and management of common smut on sweet corn. An update. Proc. Pacific Northwest Veg. Assn. p. 59-72.

Clough, G.H., P.B. Hamm, M. Baune, and L. du Toit. 2001. Cultivar selection and fungicide application for control of common smut of sweet corn. HortScience 36:439 (abstr.).
Clough, G.H., P.B. Hamm, S. Blatchford, and L. du Toit. 2003. Control and management of common smut on corn in the Columbia Basin of Oregon and Washington. 2003 Rpt. Agr. Res. Foundation Ore. Processed Veg. Commission. p. 88-101.

Horst, R.J., T. Engelsdorf, U. Sonnewald, and L.M. Voll. 2008. Infection of maize leaves with Ustilago maydis prevents establishment of $\mathrm{C}_{4}$ photosynthesis. J. Plant Physiol. 165:19-28.

Hortik, H.J. and C.Y. Arnold. 1965. Temperature and the rate of development of sweet corn. J. Amer. Soc. Hort. Sci. 87:303-312.

Immer, F.R. and J.J. Christensen. 1928. Determination of losses due to smut infections in selfed lines of corn. Phytopathology 18:599-602.

Johnson, I.J. and J.J. Christensen. 1935. Relation between number, size and location of smut infections to reduction in yield of corn. Phytopathology 25:223-233.

Oregon State University Cooperative Extension Service. 2004. Sweet corn for processing. 25 Jan. 2010. $<\mathrm{http} / /$ nwrec.hort.oregonstate.edu/corn-pr. html>.

SAS Institute Inc. 2004. SAS/STAT® 9.1 User's Guide. SAS Institute Inc., Cary, NC.

Stall, W.M., L. Waters, Jr., D.W. Davis, C. Rosen, and G.H. Clough. 1989. Sweet corn production in: The National Corn Handbook. Purdue Univ. Coop. Ext. Serv., West Lafayette, IN.

U.S. Department of Agriculture. 2009. Census of agriculture. National Agricultural Statistics Service. 20 Jan. 2010. <http://www.agcensus.usda. gov/index.asp>.

White, D.G. 1999. Compendium of corn diseases. 3rd Ed. Amer. Phytopathol. Soc., St. Paul, MN. 